The style of Chancellor's book is compact. It would seem that no discovered fact has been omitted. For example: 'After landing in New York, Audubon did not make straight for Mill Grove. Instead, he walked thirty miles to Greenwich, Connecticut, to cash a letter of credit. On the way he succumbed to yellow fever ...' and we learn that two Quaker ladies 'saved his life'. But there is no further or prior mention of these ladies, or of yellow fever, or Greenwich, or why the money was there. But, I suppose, life is like that, and certainly Audubon's was, as he moved from meeting Sir Walter Scott (each lauded the other), antagonising John Keats (of all people, but some of brother George Keats's money had gone down the Audubon drain), being captured by HMS Rattlesnake (not T. H. Huxley's vessel), suffering patrons (the Earl of Kinnoull thought his birds 'alike' and a 'swindle'), and generally promoting his image of a backwoodsman who occasionally hit town.

The appearance of the book is splendid, a sort of poor man's Birds of America, with several colour and many black and white illustrations of the famous watercolours. They alone are sufficient for us to agree that 'John James Audubon is the patron saint of birds', and the text is equally adamant that he is patron saint of nothing else.

ANTHONY SMITH

\title{
Encounters with Nature, by Leslie Brown. Oxford UP, $£ 6.50$.
}

For many years I eslie Brown has been entertaining and instructing us about the wildlife and ecology of Africa and elsewhere and has established a reputation for original observation, lively description and lucid comment. In this new book he looks back on his life as a naturalist and recounts some of his outstanding experiences and adventures. So in one volume we have what might be called 'the quintessence of I eslie Brown' - a welcome summary of several of his earlier books along with other material.

His themes range widely: aardvarks, badgers and honey badgers, beavers, chimpanzees, nightjars, otters, pelicans, tigers and whale sharks. How he sought long and hard for that rare and splendid antelope, the mountain nyala, makes a most engaging narrative that takes us up into the vast, bandit-infested, rainy, cold (yet sometimes scorching) uplands of Ethiopia, which are also the home of Simien foxes, walia ibexes and lammergeiers.

But for most of us I,eslie Brown is the eagle man or the flamingo man and for me it is the accounts of these two groups of birds that make the best chapters. The flamingo episodes are especially vivid: we rarely do get to feel how almost unlivable life can be on an equatorial soda lake - the lead-weight heat, the awesome stench, the stultifying glare and then, totally in contrast with these horrors, the unbelievable beauty of a great throng of pink and white flamingos and their brown young ones. Few of us can go and experience truly wilderness Africa, so it is good to be assured that it still survives here and there. And it is well that writers like Leslie Brown can picture it for us so convincingly. To complement the text each of the thirteen chapters is prefaced by very lively, full-page drawings by Doris Tischler; and the colour photograph of flamingos on the dust jacket is altogether beautiful.

WIIIIIAM CONDRY

\section{The End of the Game, by Peter H. Beard. Collins, $£ 10$.}

That The End of the Game has run into a second edition suggests either that the patient is an unconscionable time dying or that the title is prematurely pessimistic. This is a strange book. According to the dust jacket, it retails the decline of Tsavo National Park in Kenya, but, with three of the five chapters concerned with other regions, there is little space left in which to develop the Tsavo theme, particularly as only 70 of the 280 or so pages contain 